\title{
Asymmetrical response of summer rainfall in East Asia to $\mathrm{CO} 2$ forcing
}

\section{Article}

Keywords:

Posted Date: August 12th, 2021

DOI: https://doi.org/10.21203/rs.3.rs-146325/v2

License: (c) (1) This work is licensed under a Creative Commons Attribution 4.0 International License.

Read Full License

Version of Record: A version of this preprint was published at Science Bulletin on August 1st, 2021. See the published version at https://doi.org/10.1016/j.scib.2021.08.013. 


\section{Abstract}

The full text of this preprint has been withdrawn by the authors due to author disagreement with the posting of the preprint. Therefore, the authors do not wish this work to be cited as a reference. Questions should be directed to the corresponding author.

\section{Full Text}

The authors have withdrawn this preprint from Research Square. 